\title{
Merpati Nusantara Airlines and the Challenges of Operating Again in the Deregulation of the Indonesian Aviation Industry
}

\author{
Basneldi $^{1}$, Budi Safari ${ }^{2}$ \\ Sekolah Tinggi Penerbangan Aviasi, Jakarta, Indonesia \\ email: basneldi69@gmail.com, budisafari77@gmail.com
}

\begin{abstract}
The research method with a qualitative descriptive approach through understanding some opinions of flight leaders, several other sources. The results of this study are an overview of all the results presented by some of the sources above, and the results of this study indicate that there is a need for strategic management, creating revenue from other sources. Airlines must maintain cash flow because it is related to sustainability. large, the growth of the middle class of passengers has increased the most, focusing on strategic routes that have not dealt directly with airlines that run the low cost carrier model, Low cost Carriers help create a surge in passengers so the government must arrange airlines that use the low cost carrier privilege, the Government must continue to build airport infrastructure. It is necessary to evaluate the business of airlines in Indonesia and, it is necessary to prepare human resources who understand the crisis and turn around strategies of Airlines.

Merpati Nusantara Airlines is a state-owned enterprise formed in 1962 as an inter-island bridge in Indonesia, February 1, 2014 stopped operating due to financial problems, and high competition due to low entry barriers and market liberalization as a result of globalization.

Dealing directly with airlines that run the low cost carrier model, Low cost Carriers help create a surge in passengers so the government must arrange airlines that use the privilege of low cost carriers, the Government must continue to build airport infrastructure, need an evaluation of the airlines business in Indonesia and, it requires preparation of human resources who understand will be a crisis and Turn around strategy from Airlines.
\end{abstract}

Keywords : Merpati Nusantara Airlines, airlines business, deregulation goverment 


\section{INTRODUCTION}

Challenges in the Indonesian Aviation Industry, of course, have increased since the trade war occurred in the last two years which has resulted in fluctuations of the dollar against the local currency of Indonesia. Air transport has an important role in fulfilling the human need for mobility that is fast, so where about srequ, ired to provide effective and efficient transportation. The transport system in the region has always been built into an unity and switching form between modes within an area. (M. Suryawan, RF, \& Fatchoelqorib, 2018). Indonesian passenger growth that exceeds Japan. Airlines owners seem to be moving on their own, even though the role of the government is needed as a maker, regulator owner, guarantor in the case of buying and leasing aircraft, because Merpati Nusantara Airline is owned by the government. Characteristics of aviation transport according to Arianto, (2018); (1) has a high speed and a long range, (2) very capital intensive, (3) very dynamic in accordance with technological changes very quickly and a very high level of competition, (4) has a very high risk, (5) is greatly influenced by the political situation, and (6) the transportation services business so that the role of services is very important. Because of constraints with capital, Merpati cooperates with the Merouke local government through Joint Operation (KSO), the route that most of the pioneering routes connecting the hinterland Papua and parts of Kalimantan.

Using small aircraft, this route is subsidized by the government and some commercial routes, the government is obliged to overcome every market failure (Ginting 2010), deregulation is the act or process of adding, eliminating, reducing all the rules of the transportation ministry. The amount of pioneering airline debt is currently around
Rp.10 trillion, and with the approval of the Debt Obligation Obligation (PKPU) by the Surabaya commercial court on October 21, 2018, PT.Merpati will not go bankrupt, it is hoped that there will be new investors who will inject fresh funds that will will be used to purchase new aircraft and arrange flight route permits and other operational investments. According to the managing director of PT. Merpati Nusantara Capt. Asep Eka Nugraha the core of the peace proposal is to be given the opportunity to operate again, have the ability to complete the agreed ruislag mechanism, why is it important to return to flight ?

Since it began operating in 1962 PT. Merpati serves many routes to remote areas and was quite successful for the 80 s to 90 s in eastern Indonesia (Arista Atmadjati) aviation business expert, and now the eastern part of Indonesia is relatively underdeveloped, the constraints faced are transportation facilities Because the area consists of islands, air transportation is the main choice, PT.Merpati Nusantara Airlines opportunities are quite a number of routes, human resources, operational systems have been integrated, since it stopped operating 5 years ago 19 routes were taken over by other airlines like Susi Air, Garuda Indonesia and Nam Air. PT Merpati still has a chance, said Arista Atmadjati, exemplified that Batik Air using a full-jet engine aircraft must fly at a minimum runway of 2,300 - 2,500 meters and of course only in the provincial or city capital is rather large.

PT. Merpati Nusantara should avoid head-to-head with airlines such as Batik, Sriwijaya or Lion, PT. Merpati focus on playing on the runway with a length of 1,2001,500 meters, because of the narrow competition and most airports in eastern Indonesia. Merpati must focus on small aircraft such as Twin Otter or other aircraft 
specifically for airing on short routes and hard to reach areas large bodied aircraft. Fuel conservation means managing aircraft operations and conditions.

(Maintenance) to minimize the total airline operating costs (Tjahjono, 2018). The structure of aviation financing includes the two largest variables, namely direct cost $(57 \%)$ and effect cost (34\%) and 5\% each, namely indirect cost and overhead cost (Irianto, 2018). Direct cost in the aviation industry which is the largest cost structure is direct traffic cost is $6 \%$, passenger commission with $5 \%$, cost of conservation is only $1 \%$ and credit card commission and on board are only $0 \%$ (zero percent) respectively. Other large direct cost variables are direct flight cost $(51 \%)$ and aircraft fuel $(36 \%)$ while other financing is maintenance $(7 \%)$, handling (1\%), financing that is only $1 \%$ each is landing, and air traffic control. At indirect costs, the cost for cockpit crew and cabin crew person is $5 \%$, while aircraft maintenance is only $0 \%$ (zero percent). For overhead costs are the costs for the station $1 \%$, administration by $3 \%$, while the marketing and sales organization costs are only $0 \%$ (zero percent). The cost structure of the effect with a fairly large percentage of $34 \%$ in aircraft lease, while not large is depreciation aircraft with $3 \%$ and insurance is only $0 \%$ (zero percent). Data on operating revenues and costs incurred in a company must be regularly reconciled and reported in the profit and loss statement (matching system); deferral is a delay in recognizing fees for transaction fees that have been paid; Prepaid expenses are costs that have benefits in the short-term time period that is described in the current group balance sheet and becomes a cost on a regular basis month after month. (Sudarno, and Ryan Firdiansyah, 2018). According to Rompas, (2018) from IATA, the effect of fuel charges and the increase in the USD impacted flights other than in Indonesia, also in India. The stakeholders must be prepared to accept this increase because our foreign exchange reserves are still good. Intense competition from the LCC, LCC growth, infrastructure did not compensate for the increase in passenger numbers. The LCC resulted in a surge in passengers so there must be regulations to regulate it.

Indonesia, according to IATA in 2016, is estimated that since 2016 with 120 million passengers a year in the period of 20 years to 2036 will experience growth to 281 million passengers, still below India with 464 million passengers in Asia. China is very far above, in 2036 with growth reaching 1.427 billion passengers (Rompas, 2018). The growth of flights in Indonesia is still large. IATA used to set ticket prices but on November 1, 2019 IATA no longer managed ticket prices and was immediately released to the Airlines. Data from the Central Statistics Agency 2018 shows, the growth of domestic flight passengers in the period 2013 - 2018 experienced ups and downs, down from 2013 with $2.09 \%$ up to $16.97 \%$ in 2016 but dropping dramatically to $7.48 \%$ in 2018 . International flights have not decreased, growth from 1.3 million passengers in early 2018 increased to 1.6 million passengers in the August 2018 period (Charles, 2018).

The results of previous studies, explained that the airline owner must invest more capital in the aviation business and that large airlines have performance problems and should be divided into several divisions, each of which handles certain markets (Pires, HM \& Fernandes, 2016). Unhealthy competition in The aviation market is usually based on an analysis of changes in the aggregate measures of airline performance, such as average fares, traffic and revenue. Overall, that stressed airlines will tighten competition and Low Cost Carrier capacity growth shows there is 
market friction in competition (Lee, 2010). Research results (Pamungkas \& Suhadak, 2017), show that, Avtur Prices, Exchange Rates, and Inflation have a significant effect on Net Profit Margin (NPM). From the results of Setyawan's study, (2014) conclusively that the sectors most affected by rising fuel prices are the transportation sector both land, air and water are also strongly influenced by rising fuel prices, because vehicles that operate depend on fuel.

\section{METHOD}

This research uses descriptive qualitative method, because there is a problem or issue that must be explored. The study uses library data and the results of exposure of several speakers, namely the leader of Merpati Nusantara, the leader of Sriwijaya Air, the leader of Citilink, several lecturers in the field of aviation and aviation practitioners who can be accounted for.

\section{DISCUSSION}

Five external environmental factors, according to Nitidihardjo, (2018) from INACA are seen as influential for the aviation industry namely; 1) Regulation and deregulation, (2) Economic growth, (3) Social and political climate, (4) Markets and (5) Competition (figure 1). Rupiah depreciation against US Dollar; (1) affect the national airline revenue, (2) make maintenance and operational costs rise, (3) revenue in rupiah, expenses in US dollars (maintenance, leasing, fuel), (4) public purchasing power decreases, potentially reducing travel by airplane, and (5) Indonesia's economic growth projection is very careful, in ASEAN under Vietnam, Burma, the Philippines, Cambodia and Laos (Nitidihardjo, 2018).

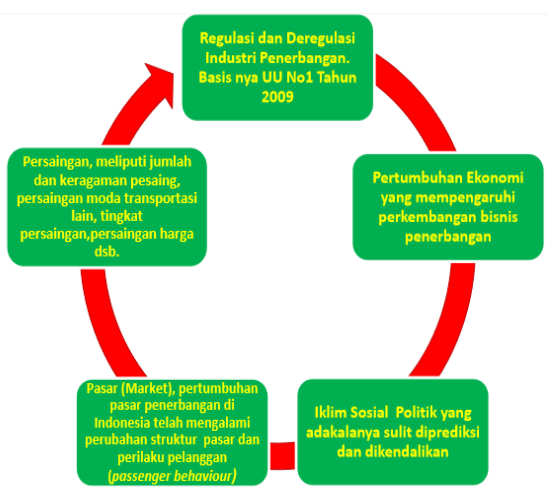

Gambar 1. Lima faktor lingkungan eksternal

$40 \%$ increase in fuel prices where the operational costs of fuel calculations are around 30 to $40 \%$ of the total operational costs. In this case, according to Nitidihardjo, INACA has had a review of the cost rates to the government. Some airlines in the world have implemented many cost savings for operational load in order to survive (Nitidihardjo, 2018). The weakening of the rupiah against the US Dollar is very influential on national airline revenue because revenue is in the form of rupiah but expenditure is in the form of dollars, so it is very influential especially the fluctuating value of the Rupiah against the dollar value. Due to the current global economic situation for Etihad Airways closed the First and Business Class Lounges in London, reducing several flight routes (Nitidihardjo, 2018). The weakening rupiah exchange rate against the US Dollar has been seen since January 2018 with Rp. 13,447, to Rp. 15,444, - in December 2018, based on Bank Indonesia Middle Rate in 2018 which was seen to be weaker than in 2017, in the same period of Rp. 13,427 to Rp. 13.4254, - (Charles, 2018, Nitidihardjo, 2018).

Reducing the rupiah will be difficult for airlines because almost all costs are in dollars to pay for planes, insurance, land handling, 
crew, maintenance, spare parts, fuel (Iqbal, Dennis, \& Charles, 2017). The main currency in the aviation business is the dollar, making slight changes in the dollar against the rupiah can change costs, making the cost of the aviation business dependent on the price of the dollar against the rupiah. Fluctuations in fuel prices can be an opportunity for airlines but a decrease in the exchange rate of the rupiah against the dollar causes the opportunities and benefits received by airlines from the reduction in fuel prices may not be optimal (Ricardianto, Djajaputra, \& Martono, 2017). Nearly $60 \%$ of airline costs are in US Dollars, the weakening of the rupiah is increasingly having an impact on airlines combined with high jet fuel prices which always change every two weeks, which will greatly affect operational costs. Specifically ticket prices (Simarmata, Charles, \& Rizaldy, 2014).

Irianto, (2018) added in the revenue management strategy, increasing and reducing passenger income in USD, reviewing passenger revenue for each sector on the number of flights (flight number). Addition will also have an impact on; Gain More Revenue to Maximize Profitability and Optimize non-promo subclasses allocation. While the reduction will have an impact on; (1) Gain More Revenue to Minimize Loss, (2) Optimize Sub-Classes Allocation Promo, (3) Evaluate QG vs O. C Strategy, (4) Gain More Market Share, and (5) Network Traffic Optimization (Figure2)

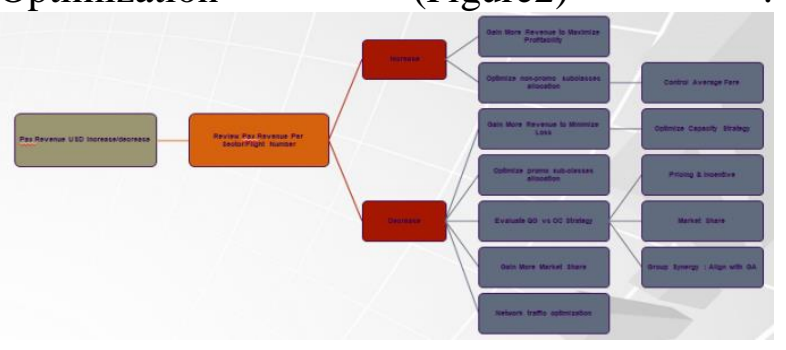

Figure 2. Revenue Management Strategy
In terms of revenue management, Citilink's opinion above supports previous research such as, simulation results according to Gorin \& Belobaba, (2004) which show that these steps can be greatly influenced by competitive revenue management situations. Revenue management is a method for maximizing total airline revenue. The goal is different from "simple" which has the highest load factor or even from having the highest possible income for each passenger (yield) (Lenoir \& Bontemps, 2011). Several aviation industry researchers and consultants have proposed various static and dynamic mechanisms to control income management decisions throughout the alliance (Wright, Groenevelt, \& Shumsky, 2010). Several aviation industry researchers and consultants have proposed various static and dynamic mechanisms to control income management decisions throughout the alliance (Wright et al., 2010). How is the revenue management system according to Zaki, (2000) used in the aviation industry to optimize profits.

Revenue management cannot work without adequate capacity, demand and price estimates. Airlines also have to make various operational decisions every day. Some of the most financially profitable operational decisions are made using income management techniques. The main goal of income management (Yeoman \& McMahon-Beattie, 2017), is to sell the right product to the right customer and at the right time for the right price. Since the deregulation of the US aviation industry, and the advent of the internet as a distribution channel, revenue management has matured. Some strategic steps in the opinion of the airline leadership are; (1) Cash flow / CashFlow is maintained prudently, (2) Consider raising ticket prices, (3) Innovative and creative in a disruptive situation, (4) Reducing / cut capacity, and (5) Ancillary Revenue (Nitidihardjo, 2018). 
Nitidihardjo added that consolidation had to be carried out by; (1) Negotiating with lessors, airport operators (airport charges), (2) Cost saving in several areas that can be carried out in a sluggish economic situation and (3) Restructuring Route (Nitidihardjo, 2018). Rupiah depreciation against US Dollar; (1) affects the national airline revenue, (2) makes maintenance and operational costs rise, (3) revenues in rupiah, expenses in US dollars (maintenance, leasing, fuel), (4) people's purchasing power decreases, potentially reducing travel by airplane, and (5) projections of Indonesia's economic growth are very careful, in ASEAN under Vietnam, Burma, the Philippines, Cambodia and Laos (Nitidihardjo, 2018).

Since deregulation in 2000, airline business conditions have been bumpy, more or less 18 airlines have gone bankrupt not because of mis-management or because of the economic of scale. Some actions as a total evaluation are needed according to Nursatyo from Sriwijaya Airlines, due to several things including; (1) over supply, (2) low yield, (3) predatorism, (4) restricted profit margin and (5) resistance to the economy. Every airline must have a survival plan. For example in Sriwijaya Airlines (Nursatyo, 2018), several conservative strategies were applied such as; (1) integrity, (2) customer focus, (3) adaptive and innovative, (4) responsibility, (5) excellent service, and (6) synergy and unity. Also added are several important strategy steps, including; (1) right-sizing production, (2) focus on service quality, (3) creating blue ocean routes, (4) creating loyalty programs, (5) expanding international routes for USD revenue, (6) efficiency and (7) marketing digitally. Viewed from the macro side, currency issues and price raised fuels cause economic growth to fall, purchasing growth to fall, so there is economic turn down. In terms of the micro cost increase, load factors decrease resulting in economic growth, purchasing growth and industry growth, so there is a downturn in the economy, so there is an adjustment in prices and the consequences.

The strategy for management, according to Irianto, (2018), to increase revenue is to internally look at how the market share is related to the price given and externally see how delayed time can be seen on a daily basis where it used to be only weekly or monthly. Implement pricing strategies on routes that have already earned profit. Reduction in frequency on routes that have already earned profit. Existing frequencies must be optimized to cover direct costs. Perform additional frequencies at weekends. Increase revenue in cargo shipments. Conduct efficiency in all fields so that fleet cost can decrease. Tjahjono (representative of KNKT), explained that, the strategy to reduce costs is the use of insurance, because insurance in Indonesia is the highest in ASEAN (Tjahjono, 2018). Charles, (2018), added, forecasting on exchange rates and crude price oil needs to be done by airlines in order to be able to give an idea and can anticipate the occurrence of a rising dollar which greatly affects fuel costs. Every Airlines must be smart to look for innovations. the right one is just thinking about how to get passengers. Passengers from airlines grow each year. Utilization to increase frequency. But in fact Airlines do not calculate revenue from cargo. Some strategies to increase more revenue can also be done through; (1) reducing losses on existing routes, (2) increasing profits on existing routes and (3) increasing opportunities on new routes (Nitidihardjo, 2018). To overcome the problem of avtur prices according to Adam, (2019), it is hoped that the government can implement several strategies such as; (1) providing distribution subsidies (avtur one price), (2) building distribution networks on 
important routes such as Kualanamu, Jakarta, Makassar with guaranteed price equal or cheaper from neighboring countries and even Asia Pacific. The strategy adopted according to Simarmata (et al., 2014) is related to fuel conservation policies; such as implementing a Cost Index, Fuel Tanking, choosing Optimal Level Flights, focusing on flight engineering and maintenance to improve efficiency in the use of aviation fuel or fuel, or even change aircraft types. Another strategy according to Charles, (2018) so that prices are affordable and sustainable can be done also through; (1) optimizing aircraft utilization, (2) fuel conservation and (3) seeking additional revenue (figure 3) and how the strategy for company sustainability can be supported by aviation operators and regulators and suppliers (figure 4).

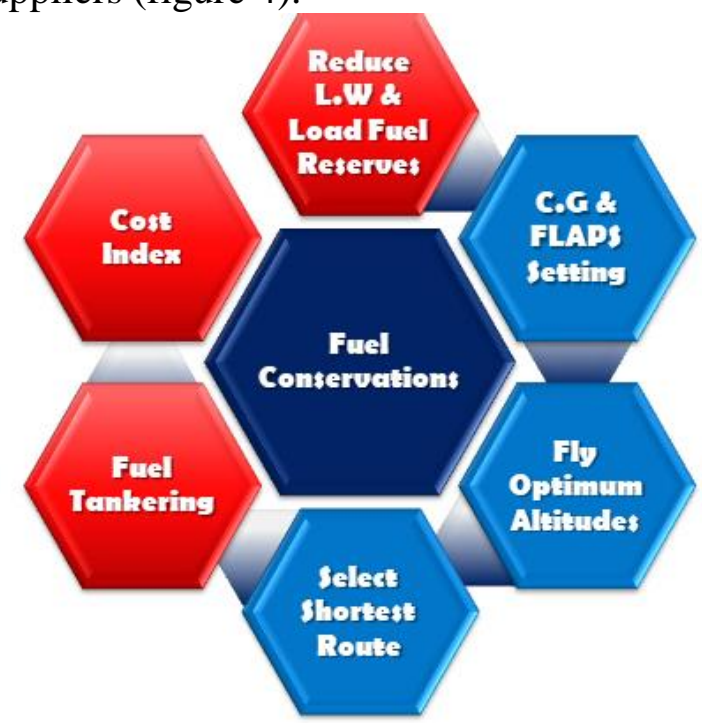

Sources: Boeing Manufactures (2007) Figure 3: Affordable Prices \& Survive

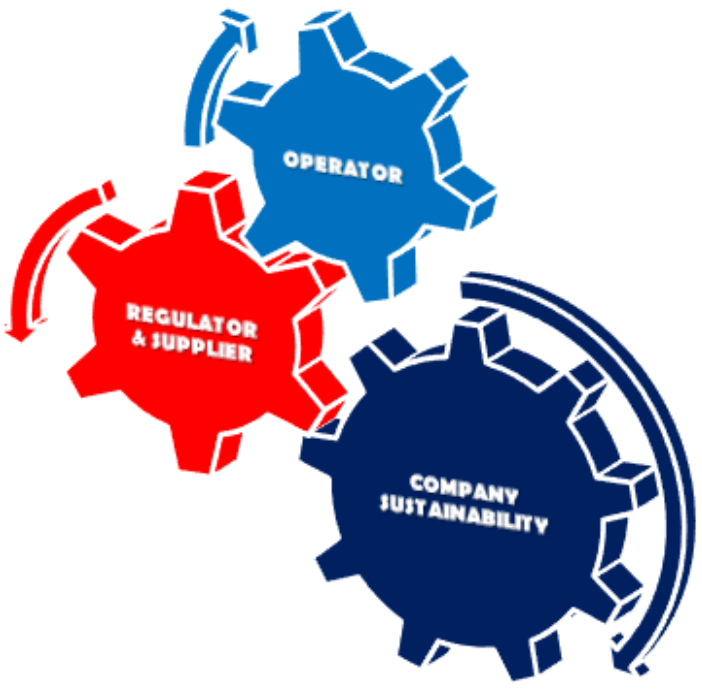

Sources: Boeing Manufactures (2007) Conclusion

Figures 4: Company Sustainability

As long as the state of the global economy is still shrouded in a trade war waged by the US President, Trump, we do not expect much in the near future the situation of the national aviation industry which has taken various steps to overcome turbulence in the weakening of the rupiah and the rise in fuel prices, can again recover from external pressure and the uncontrollable factor. The airline business is very sensitive because there are many external factors that affect it, such as fuel, forex, union and macroeconomics so that people who are brave in this industry are needed. Airline must be creative to manage these risks. LCC has more opportunities to innovate and creativity is compared to FSC, because there are more opportunities to increase revenue beyond the ticket price (Ancillary service). Ticket prices can no longer be maintained as a competitive tool. Airline must be able to maintain cash flow. Doing efficiency by increasing utilization, choosing more appropriate routes, alternate landing, profitability, crew patterns etc. Enlarge Cargo and Ancillary Revenue. 
Concluded five factors that affect the airline industry. (1) Strategic steps are needed to address turbulence fuel (2) There is a need for strategic management, creating revenue from other sources Airlines must maintain cash flow because it is related to sustainability, (3) Direct cost has the largest cost contribution, (4) The growth of the middle class of passengers has increased the most, focusing on strategic routes that have not yet come face to face with airlines that run the low cost carrier model, Low cost Carriers help create a surge in passengers so the government must arrange airlines that use low cost carrier privileges, (5) Government must continue to build airport infrastructure. It is necessary to evaluate the business of airlines in Indonesia and, it is necessary to prepare human resources who understand the crisis and turn around strategies from Airlines.

\section{REFERENCE}

Adam, H. (2019). Gagal Pulang Kampung, Karena Tiket Mahal, Apa Sebab? Retrieved from helmiadamchannel.blogspot.com. June $05,2019$.

Charles. (2018). How Indonesian Airline Industry Survive From Currency and Fuel Price Turbulence. In International Seminar. Jakarta: ITL Trisakti.

Davidson, C., Newes, E., Schwab, A., \& Vimmerstedt, L. (2014). An Overview of Aviation Fuel Markets for Biofuels Stakeholders (No. (No. NREL/TP-6A2060254).). Overview of Aviation Fuel Markets for Biofuels Stakeholders. https://doi.org/10.2172/1148623

Eshraghi-aran, M., \& Soltani, M. (2017). The Impact of Airline Bankruptcies on passengers and Airports (A comparative study on United States and European
Union). JOURNAL OF TRANSPORTATION RESEARCH, 14(1), 184-199.

Forsyth, P., \& Dwyer, L. (2007). Exchange Rate Changes and the Cost Competitiveness of International Airlines: The Aviation Trade Weighted Index.

Global, T. F. (2018). Oil Prices and the Airline Industry. Retrieved from www.tradefinanceglobal.com. July 19, 2018.

Gorin, T., \& Belobaba, P. (2004). Impacts of entry in airline markets: effects of revenue management on traditional measures of airline performance. Journal of Air Transport Management, 10(4), 257-268.

Iqbal, M., Dennis, K., \& Charles. (2017). THE IMPACT OF CURRENCY EXCHANGE RATE AND AIRCRAFT TYPE SELECTION ON INDONESIA AIRLINES BUSINESS SUSTAINABILITY. In Advances in Engineering Research (AER), volume 147 Conference on Global Research on Sustainable Transport (GROST 2017). Atlantis Press.

Irianto, A. (2018). How Indonesian Airline Industry Survive From Currency and Fuel Price Turbulalence. In International Seminar. Jakarta: ITL Trisakti.

Jochumzen, P. (2010). Essentials of Macroeconomics (1st Eds.). Retrieved from

https://bookboon.com/en/search?q=Peter +Jochumzen

Kompas tim. (2019). Kenaikan Tarif Penerbangan Dinilai Tidak Biasa. Kompas. Retrieved from kompas.id. June 19, 2019.

Lee, H. R. (2010). Bankruptcy and Low Cost Carrier Expansion in the Alirline Industry. IEW - Working Papers 502. 
Institute for Empirical Research in Economics - University of Zurich.

Lenoir, N., \& Bontemps, C. (2011). Airline pricing and revenue management. Retrieved from www.enac.fr/recherche/leea

Niidihardjo, W. (2018). How Indonesian Airline Industry Survive From Currency and Fuel Price Turbulence. In International Seminar. Jakarta: ITL Trisakti.

Pamungkas, D. P., \& Suhadak, S. (2017). The Effect of Jet Fuel Price and Macroeconomics Variables on Profitability of Airline Industry in Asia (Study at Airline Companies in Indonesia, India, and China Period 20062015). Jurnal Administrasi Bisnis, 50(3), 208-217.

Pires, H. M., \& Fernandes, E. (2016). Indebtedness and bankruptcy costs in the airline industry. International Journal of Aviation Management, 32(3), 105-124.

Ricardianto, P., Djajaputra, G., \& Martono, K. (2017). Air Transport and Tourism in Indonesia. IOSR Journal of Applied Chemistry, 10(5), 01-19. https://doi.org/10.9790/57361005010119.

Ryan Firdiansyah Suryawan, M. Fatchoelqorib, (2018). Penerbangan Perintis dalam Mengembangkan Perekonomian di Pulau Karimun jawa, Jurnal Manajemen Transportasi dan Logistik, 161-168.

Rompas, R. (2018). Tantangan di Industri Penerbangan Indonesia. In International Seminar. Jakarta: ITL Trisakti.

Setyawan, D. (2014). The Impacts of the Domestic Fuel Increaseson Prices of the Indonesian Economic Sectors. In Conference and Exhibition Indonesia Renewable Energy \& Energy Conservation [Indonesia EBTKE
CONEX 2013]. (pp. 47-55). Jakarta: Energy Procedia. Elsevier Ltd. https://doi.org/10.1016/j.egypro.2014.01. 195

Simarmata, J., Charles, \& Rizaldy, W. (2014). The Impact of Fuel Increase and Currency Exchange Depreciation on Indonesia Aviation Industry Sustainability. Jurnal Manajemen Transportasi \& Logistik (JMTransLog), 1(3), 199-208.

Singh, V., \& Sharma, S. K. (2015). Fuel consumption optimization in air transport: a review, classification, critique, simple meta-analysis, and future research implications. European Transport Research Review, 7(2), 12.

Sudarno Sudarno, Ryan Firdiansyah uryawan, (2018). Biaya Perawatan Pesawat Udara dan Pedoman Perlakuan Akuntansi (Studi Pustaka), 1-12.

Tjahjono, S. (2018). Fuel Conservation Program. In International Seminar. Jakarta: ITL Trisakti.

Wresti, M. C. (2019). Penerbangan Dunia Lesu. Retrieved from kompas.id. June 12, 2019.

Wright, C. P., Groenevelt, H., \& Shumsky, R. A. (2010). Dynamic revenue management in airline alliances. Transportation Science, 44(1), 15-37.

Yeoman, I. S., \& McMahon-Beattie, U. (2017). The turning points of revenue management: a brief history of future evolution. Journal of Tourism Futures, $3(1), 66-72$.

Zaki, H. (2000). Forecasting for airline revenue management. The Journal of Business Forecasting, 19(1), 2.

Id.m.wikipedia.org

Kumparan bisnis 24 September 2018 Fadhly Fauzi Rachman - detikFinance 21 
Desember 2018. Pemerintah siap lepas seluruh saham agar merpati terbang lagi.

Ginting (2010) peranan subsidi terhadap perekonomian Indonesia, pusat pengkajian, pengelolaan data dan informasi (P3DI) DPR RI. Badan Pengembangan Bahasa dan Perbukuan, Pendidikan dan Kebudayaan.

Sitepu Mehulika 15 nov 2018 BBC News Indonesia, Merpati: dapatkah kemabali terbang tinggi mengulangi kejayaan masa lalu? 